Article

\title{
People's Knowledge of Illegal Chinese Pangolin Trade Routes in Central Nepal
}

\author{
Sandhya Sharma ${ }^{1}$, Hari Prasad Sharma ${ }^{2, *} \mathbb{0}$, Hem Bahadur Katuwal ${ }^{3,4} \mathbb{D}$, Chanda Chaulagain 5 \\ and Jerrold L. Belant ${ }^{6}$ \\ 1 Himali Conservation Forum, Taplejung 57500, Nepal; sandhyasharma198@gmail.com \\ 2 Central Department of Zoology, Institute of Science and Technology, Tribhuvan University, \\ Kathmandu 44600, Nepal \\ 3 Center for Integrative Conservation, Xishuangbanna Tropical Botanical Garden, Chinese Academy of \\ Sciences, Mengla 666303, Yunnan, China; hembahadur@xtbg.ac.cn \\ 4 University of Chinese Academy of Sciences, Beijing 100049, China \\ 5 Pashupati Multiple Campus, Kathmandu 44604, Nepal; sharma.chanda2011@gmail.com \\ 6 Global Wildlife Conservation Center, State University of New York College of Environmental Science and \\ Forestry, Syracuse, New York, NY 13210, USA; jbelant@esf.edu \\ * Correspondence: hpsharma@cdztu.edu.np
}

Received: 6 May 2020; Accepted: 13 June 2020; Published: 16 June 2020

check for updates

\begin{abstract}
Chinese pangolin populations are declining globally due to illegal wildlife trades in its range countries, especially China and Vietnam, where the largest markets for this species exist. Identifying the trade routes is crucial for developing conservation plans for the pangolin and understanding the attributes of the individuals involved in the illegal trade. We aimed to identify local trade routes and the socio-economic status of people involved in pangolin trades from the Gaurishankar Conservation Area [a Protected Area (PA)] and the Ramechhap district [a non-Protected Area (non-PA)] of Nepal. We found that pangolin traders were typically poor, illiterate, unemployed, male, and of working age (17-40 years old). Confiscation rates of pangolin parts were higher in non-PAs than Pas as the illegal trade routes seemed to differ between the PAs and non-PAs. From 2014 to 2018, the prices of pangolin scales in PAs and non-PAs increased by 50\% and 67\%, respectively. Our results highlight locals facilitating the trade of pangolins, therefore we recommend the need for other income generating sources such as ecotourism or providing incentives to promote local industries as well as to establish Community Based Anti-Poaching Units among range countries and trade route countries to control the trade of this globally threatened species.
\end{abstract}

Keywords: Nepal; pangolin; poor communities; protected area; traders; unemployed; working age group

\section{Introduction}

Illegal trades act as a major threat to the conservation of pangolins in Africa and Asia [1] and has resulted in local and international overexploitation of pangolins for meat and traditional medicine, particularly in China and Vietnam [2-6]. Most pangolins consumed in China and Vietnam are trafficked from neighboring Asian countries, even though the Convention on International Trade in Endangered Species of Wild Fauna and Flora (CITES) banned international commercial trade for the wild pangolin and its body parts $[7,8]$. Bans on international trade may not ensure the conservation of pangolins unless there are also changes in consumer behavior [9]. Emerging evidence also suggests that allopathic medicines are unlikely to become substitutes for wildlife-derived traditional medicines [10]. Domestication or wildlife farming could also potentially address public demand 
for these endangered species [11], though wildlife farming has been proposed as a form of demand reduction, despite the increasing evidence that indicates it is not successful in reducing demand, including for pangolins [11,12].

Chinese pangolins (Manis pentadactyla) inhabit the Asian countries of Bangladesh, Bhutan, China, India, Lao PDR, Myanmar, Thailand, Vietnam [6], and the mid-hills region of Eastern and Central Nepal $[2,8,13,14]$. The current population of Chinese pangolins in Nepal is unknown, but the species is considered threatened due to anthropogenic activities, such as poaching for wildlife trade, and habitat fragmentation $[2,8,13,14]$. It is illegal to hunt and kill pangolins in Nepal under Nepal's National Parks and Wildlife Conservation Act 1973. Currently, the Chinese pangolin occupancy in Nepal is greater in protected areas than in non-protected areas due to the influence of human activities including agricultural practices, poaching, and development, primarily outside protected areas [15]. As a result of its overexploitation and illegal trade $[1,5,6]$, the Chinese pangolin is categorized as Critically Endangered on the International Union for Conservation of Nature (IUCN)'s Red List of Threatened Species [6] and is listed in Appendix I of CITES [16]. In Nepal, the Chinese pangolin is classified as one of the most threatened species due to exploitation, agricultural practices, poaching, and development $[2,14]$, and is protected by national law with all forms of trade banned.

The illegal wildlife trade is heavily influenced by the socioeconomic characteristics of local people [17]. Poor socioeconomic status, including poverty, unemployment, illiteracy, and lacking alternative livelihoods, drive people to participate in illegal wildlife trade [18]. Wildlife poaching activities are increasing at an alarming rate due to the growing demand in consumer markets and the high percentage of poverty in wildlife source areas [19]. Arguably, poorer communities would be less involved in wildlife poaching or trade if there was less of a demand from wealthier communities [20-22].

The primary detrimental factor in illegal wildlife trade is the high profit levels associated with the wildlife poaching [20], driven by wealthier communities [23]. Consequently, wildlife species become increasingly rare as the prices of wildlife parts, derivatives, and products increase exponentially [24]. In many developing countries, the income from illegal trade activities is often vital for sustaining the livelihoods of wildlife traders [23]. Reducing the incidences of wildlife poaching is impossible without elevating the household economies of these poachers [25]. Therefore, mitigating the effects of wildlife trade at the grassroots level should consider fulfilling the short-term goals of local communities [26]. Locals living in close proximity to wildlife thus have more incentives to manage this resource [27]. However, local people lack the luxury of supporting the conservation of wildlife species, as they are fully dependent on the wildlife's resources for their survival [26]. Additionally, indigenous people often associate with or participate in hunting wildlife as a fundamental part of their tradition, culture, or religion [19], and restrictions placed upon their practices are problematic.

Most illegal Chinese pangolin trades from Nepal are known to be motivated by the demand from China. However, specific information on the trade routes from Nepal to other countries, and information regarding people involved in Chinese pangolin trade is largely unknown [28,29]. Effective pangolin conservation requires the identification of trade routes and information on people involved in ongoing trades for developing site-specific management plans and strengthening enforcement. In this study, we aimed to identify existing wildlife trade routes, as well as the socio-economic status of people involved in Chinese pangolin trades to inform conservation management strategies. We expected that the pangolin trade would occur along multiple trade routes to reduce detection by authorities and would be influenced by the socio-economic status of local people, which can vary based on land protection status.

\section{Methods}

\subsection{Study Area}

The study area included the protected area (PA) of Gaurishanker Conservation Area (GCA: $27^{\circ} 34^{\prime} 13.97^{\prime \prime}-28^{\circ} 10^{\prime} 22.06^{\prime \prime} \mathrm{N} ; 86^{\circ} 22^{\prime} 52.35^{\prime \prime}-86^{\circ} 11^{\prime} 5.25^{\prime \prime}$ E), established in 2010, which covers 
$2175 \mathrm{~km}^{2}$, and the adjacent non-protected (non-PA) Ramechhap district $\left(27^{\circ} 49^{\prime} 55.04^{\prime \prime}-27^{\circ} 14^{\prime} 44.14^{\prime \prime} \mathrm{N}\right.$; $86^{\circ} 9^{\prime} 0.47^{\prime \prime}-86^{\circ} 27^{\prime} 7.11^{\prime \prime}$ E), which covers $1546 \mathrm{~km}^{2}$ in central Nepal (Figure 1). The GCA ranges in elevation from 1100 to $7134 \mathrm{~m}$ above sea level, with land ranging from subtropical forests to alpine and bare rock areas. There are nearly 12,000 households within the GCA [30]. Within the study area, Tamang is the largest ethnic group, representing $25.8 \%$ of the population, followed by Sherpa $(22.4 \%)$ and Chhetri (18.4\%) [31,32]. Other ethnic groups include Newar, Thangmi, Gurung, Brahman, Jirel, Kami, Damai, and Sarki. The Ramechhap District has an elevational range of 488 to $6909 \mathrm{~m}$ above sea level, and there are 43,883 households within this district [32]. Dominant vegetation in both areas include the sweet orange (Citrus sinensis), the common pear (Pyrus communis), the Nepali hog plum (Choerospondias axillaris), the gros feuille (Litsea monopetala), and the grey down balsam tree (Garuga pinnata). These areas support threatened mammal species including the red panda (Ailurus fulgens), the Asiatic black bear (Ursus thibetanus), the snow leopard (Panthera uncia), the Chinese pangolin, as well as common species such as the barking deer (Muntiacus vaginalis), the small Asian mongoose (Herpestes javanicus), the rhesus macaque (Macaca mulatta), and the grey langur (Semnopithecus schistaceus) $[8,33]$.

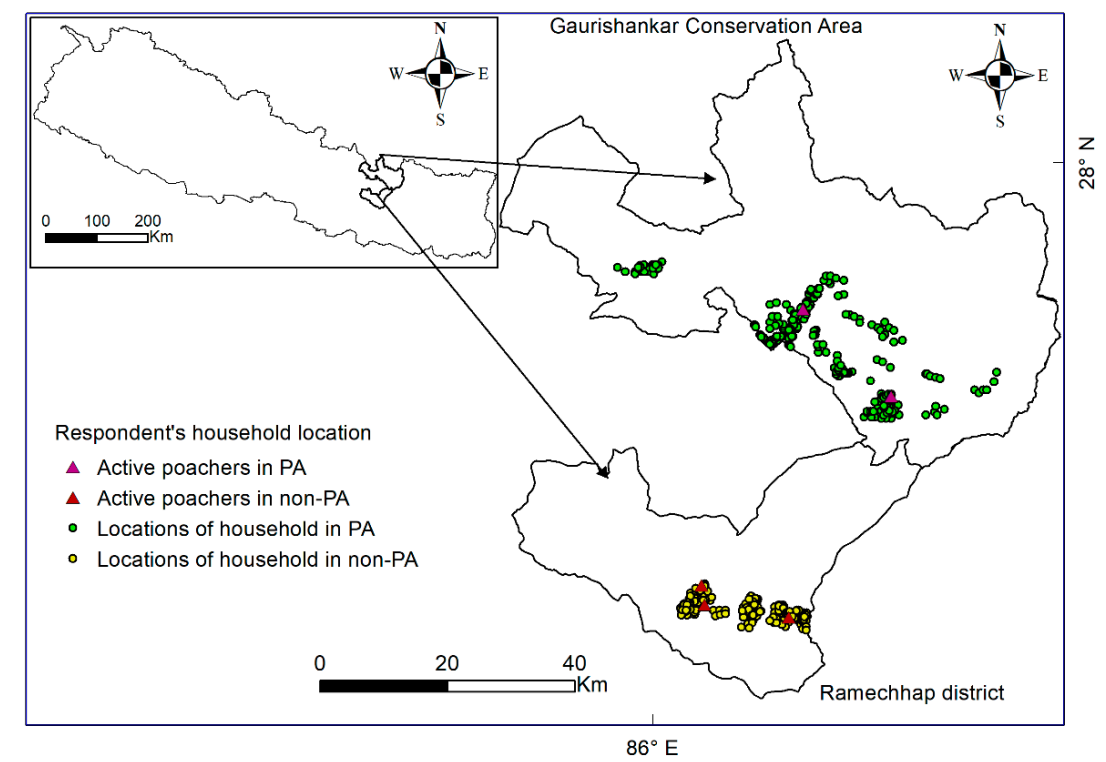

Figure 1. Locations of households (circles) surveyed in central Nepal to characterize the trade of the Chinese pangolin.

\subsection{Data Collection}

We obtained lists of households within the GCA and the Ramechhap district from rural municipalities. We then determined the sampling size for the number of households selected using Slovin's method $\left(n=N /\left(1+\mathrm{Ne}^{2}\right)\right.$ with $95 \%$ confidence intervals, where $n=$ sample size, $N=$ total number of households available, and e = standard error of sample. Following Slovin's method [34], we determined that a minimum of 388 households from the GCA (PA) and 399 from the Ramechhap district (non-PA) were necessary to obtain a suitable sample size for analyses. Therefore, we considered the minimum amount of samples required to be 400 households from each area in order to conduct a survey using semi-structured questionnaires between October 2018 and April 2019.

We used two sampling approaches to obtain survey information [35]: (1) random household sampling used to gather information about the demographic status of respondents, and (2) purposive snowball sampling from people living in the study area. Though this sampling approach does not represent the entire population, it does provide detailed information on the socio-economic status of traders involved in pangolin poaching, illegal trade routes used by traders, the price dynamics of pangolin scales from the last five years (2014-2018), and other information related to the poaching and 
trading of pangolins. We used snowball sampling to maximize information on the poaching and trading of pangolins. Further, we used two questionnaires for our sampling: one contained only questions on demographic status that were completed by all respondents, and a second containing questions regarding the poaching and trading of Chinese pangolins that was completed only by respondents familiar with these issues (Supplementary Table S1). We additionally asked these respondents about the reasons for hunting pangolins, including whether they knew about pangolin trade routes, the price of pangolins, whether pangolin trade was increasing or decreasing, who was involved in the pangolin trade, and whether the respondent was personally involved in the pangolin trade. We determined the price at which pangolin scales had been sold within the last five years from respondents during the purposive snowball sampling.

Purposive snowball sampling was done at the beginning of the survey, whereby the first respondents were selected through consultation meetings with members of local conservation institutions (i.e., the Gaurishankar Conservation Area Project of the GCA and the Divisional Forest Office of the Ramechhap district). The number of households selected for snowball sampling was 225 per area (the GCA and the Ramechhap district, respectively). Due to the sensitive nature of poaching, we signed a letter to ensure them that we would maintain their confidentiality and anonymity to facilitate accurate responses. The remaining households ( $n=175$ from each area) were selected using random sampling.

We gathered information from respondents over the age of 16 years, and recorded their educational (literate or illiterate (i.e., no formal education), employment (employed or unemployed), inhabitant (indigenous or immigrant) [36], and socio-economic statuses (sufficient income for daily livelihood or not), and sex (male or female).

We then collected information on pangolin seizure from the Gaurishankar Conservation Area Project and the Divisional Forest Office, as well as published news from 2014 to 2018. From seized records, we also obtained information on sex, age group, and ethnicity of individuals involved in the trade, along with the locations and quantities of scales seized. We also interviewed active poachers $(\mathrm{N}=5 ; \mathrm{PA}=2$, non-PA $=3)$ who were previously involved in illegal pangolin trades. All aspects of this study were approved by the Department of National Parks and Wildlife Conservation (Permission number: 564/075-076). We used Fisher's exact test, or the Chi-squared test, and the Kruskal-Wallis test for binary and numeric responses, respectively, to examine the differences in demographics of those within the PA and those in the non-PA.

\section{Results}

The respondents from the PA and the non-PA had similar demographics and socio-economic backgrounds (Table 1), except for the greater percentage (52.2\%) of respondents from the PA who had sufficient income from agriculture alone to support their livelihoods compared to the non-PA respondents $(39.9 \%)\left(\chi^{2}=6.5, p=0.01\right)$. Although agriculture was the primary occupation in both areas, crop production was less common in the non-PA due to the occurrences of more extreme weather (S. Sharma, personal observation).

Table 1. The demographics and socio-economic backgrounds of interviewed respondents from protected $(n=400)$ and non-protected areas $(n=400)$ in central Nepal, 2019.

\begin{tabular}{|c|c|c|c|}
\hline Variable & Protected Area & Non-Protected Area & Statistics \\
\hline Sex & $\begin{array}{c}\text { Female }=48.8 \% \\
\text { Male }=51.2 \%\end{array}$ & $\begin{array}{c}\text { Female }=49.7 \% \\
\text { Male }=50.3 \%\end{array}$ & Fisher's exact test, two-tailed, $p=0.83$ \\
\hline Age (years) & Median $=29$ & Median $=28$ & Kruskal-Wallis test, $\chi^{2}=2.13, p=0.14$ \\
\hline Occupation & Agriculture $=69.1 \%$ & Agriculture $=74.1 \%$ & Fisher's exact test, two-tailed, $p=0.63$ \\
\hline Education & $\begin{aligned} \text { Literate } & =86.9 \% \\
\text { Illiterate } & =13.1 \%\end{aligned}$ & $\begin{aligned} \text { Literate } & =84.2 \% \\
\text { Illiterate } & =15.8 \%\end{aligned}$ & Fisher's exact test, two-tailed, $p=0.31$ \\
\hline Religion & $\begin{array}{l}\text { Hindu }=54.2 \% \\
\text { Buddhist }=42.3 \% \\
\text { Christian }=3.5 \%\end{array}$ & $\begin{array}{c}\text { Hindu }=56.1 \% \\
\text { Buddhist }=39.7 \% \\
\text { Christian }=4.2 \%\end{array}$ & $\begin{array}{l}\text { Fisher's exact test, two-tailed, } p=0.56 \text { (Christian } \\
\text { excluded because of small sample sizes) }\end{array}$ \\
\hline Family size & Median $=5$ & Median $=5$ & Kruskal-Wallis test, $\chi^{2}=0.9, p=0.34$ \\
\hline Overall income & $87.4 \%$ sufficient & $82.7 \%$ sufficient & $\chi^{2}=0.5, p=0.47$ \\
\hline Overall income from agriculture & $52.2 \%$ sufficient & $39.9 \%$ sufficient & $\chi^{2}=6.5, p=0.01$ \\
\hline
\end{tabular}




\subsection{Characteristics of Traders/Poachers}

Respondents stated that most of those who participated in pangolin trades only did so as a consequence of their low socio-economic status, and 49.1\% (PA: $56.3 \%$, non-PA: $42 \%$ ) of respondents knew the traders and poacher's socioeconomic status. Most traders were male (PA: $92 \%$, non-PA: $100 \%$ ) and were of working age ((PA: 78.2\%, non-PA: 100\%) between 17 and 40 years old). Most people involved in the pangolin trade were indigenous (PA: 89.3\%, non-PA: 96\%), unemployed (PA: 92\%, non-PA: 94.7\%), illiterate (PA: 96\%, non-PA: 100\%), and lived in poverty (PA: $96 \%$, non-PA: $98.2 \%$ ). Among the five interviewed active poachers, all were male, unemployed, and poor; four belonged to indigenous groups and were illiterate.

Most respondents did not know why poachers would hunt pangolin (52.9\%), although about one-quarter of respondents (25.9\%) stated that pangolins were taken mainly for food and money (PA: 15.5\%, non-PA: 10.9\%); whereas $13.6 \%$ respondents speculated pangolin was hunted for food only (PA: $6 \%$, non-PA: $7.6 \%$ ) or money only (7.6\%, PA: $4.3 \%$, non-PA: $3.3 \%)$. All active poachers said they were involved in the trade for money.

\subsection{Trade Reports}

We found 32 (8 in PAs, 24 in non-PAs) arrests regarding the illegal trade of Chinese pangolins from 2011 to 2019. There were 12 times more scales seized from non-PAs (542 kg) than from PAs $(45 \mathrm{~kg})$. Men were predominantly involved in the pangolin trade (PA: 75\%; non-PA: 94\%), and all traders involved were of working age. One of the active traders started in the pangolin trade at the age of 17 , and others became active when over 40 years old. People of many ethnic groups were reportedly involved in poaching of pangolin; most frequently, the poachers were of Tamang (non-PA) and Sherpa (PA) groups (Figure 2). Over $68.8 \%$ of pangolin seizure cases were reported from non-PAs (Kathmandu: $46 \%$, Sindhupalchowk: 18.8\%, Terai region bordering India: 7\%, and Nuwakot, Bhaktapur and Sarlahi: 3.1\%) and from PAs (Sindhupalchowk border with China: 21.9\% and Dolakha: 3.1\%).

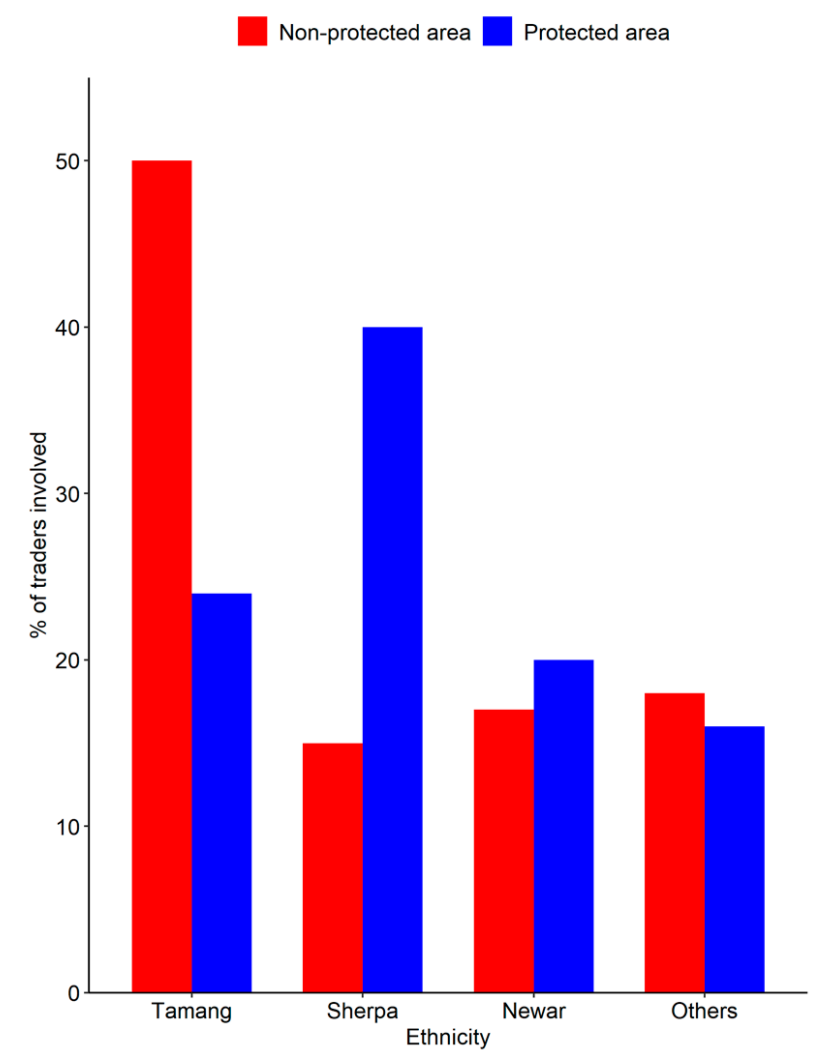

Figure 2. Members of various ethnic groups who were involved in illegal pangolin trades in central Nepal. 


\subsection{Trade Routes and Prices}

Though $29.2 \%$ of respondents (PA: $21.2 \%$, non-PA: $8 \%$ ) thought that the poaching of Chinese pangolins had stopped or decreased, whereas 50.9\% (PA: 27.9\%, non-PA: 22.7\%) thought that poaching had not stopped or decreased. From both the PA and non-PA, Chinese pangolins (including the live animal and their scales or skins) were reported traded to China from the Nepal-Tibet border. About $48 \%(n=192)$ of respondents identified three illegal trade routes from the PA; of whom (1) 31\% $(n=124)$ mentioned the GCA-Lamabagar-Lapchi-China route, (2) $11 \%$ $(n=44)$ mentioned the GCA-Sindhupalchok-Tatopani-Kodari-China route, and (3) $6 \%(n=24)$ described the GCA-Kathmandu-Kalani/Galchi/Tokha-Betrawati-Dhunche-Rasuwagadi-China route (Figure 3). Four trade routes were suggested from the non-PA: (1) Ramechhap-KavreSindhupalchok-Tatopani-Kodari-China (27\% of respondents), (2) Ramechhap-Solukhumbu-Namche Baazar ( $9 \%$ of respondents), (3) Ramechhap-Dolakha-Lamabagar-Lapchi-China (7\% of respondents), and (4) Ramechhap-Kathmandu-Kalani-Galchi-Tokha-Betrawati-Dhunche-Rasuwagadi-China ( $2 \%$ of respondents). Only one respondent from the non-PA said they traded pangolin scales through the Ramechhap-Kavre-Sindhupalchowk-Tatopani-Kodari-China route, whereas other active poachers hesitated to share their illegal trade route.

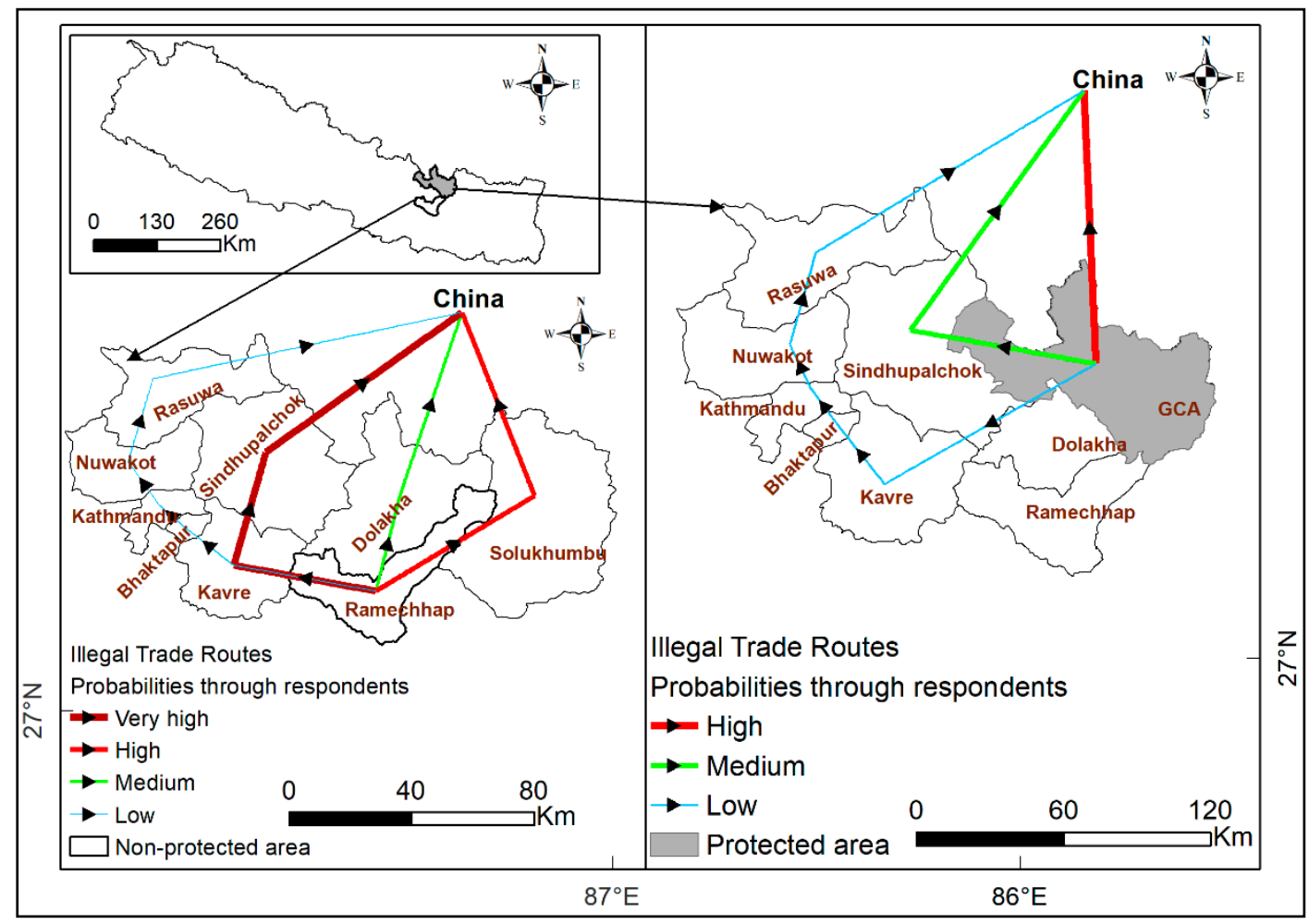

Figure 3. Illegal trade routes for Chinese pangolins and their parts in protected and non-protected areas in central Nepal.

About 22\% of respondents (PA: 15\%, non-PA: 7\%) believed they knew the cost of pangolin scales. They also stated that the price of pangolins scales had increased by 33\% in the PA and by $38 \%$ in the non-PA between 2014 and 2018. The average reported price in the PA was 12,000 NPR/kg (USD \$109/kg) in 2014 and 18,000 NPR/kg (USD \$163/kg) in 2018; in the non-PA, the cost per kg of pangolin scales was 15,000 NPR/kg (USD \$136/kg) in 2014 and 25,000 NPR/kg (USD \$218/kg) in 2018 (Figure 4). One of the active poachers from the PA stated that he sold pangolin scales at the rate of $11,000 \mathrm{NPR} / \mathrm{kg}$ (USD \$96/kg) in 2011, whereas two active poachers from the non-PA stated that prices for the scales in 2010 and 2011 were 12,000 NPR/kg (USD \$109/kg) and 13,000 NPR/kg (USD \$114/kg), respectively. 


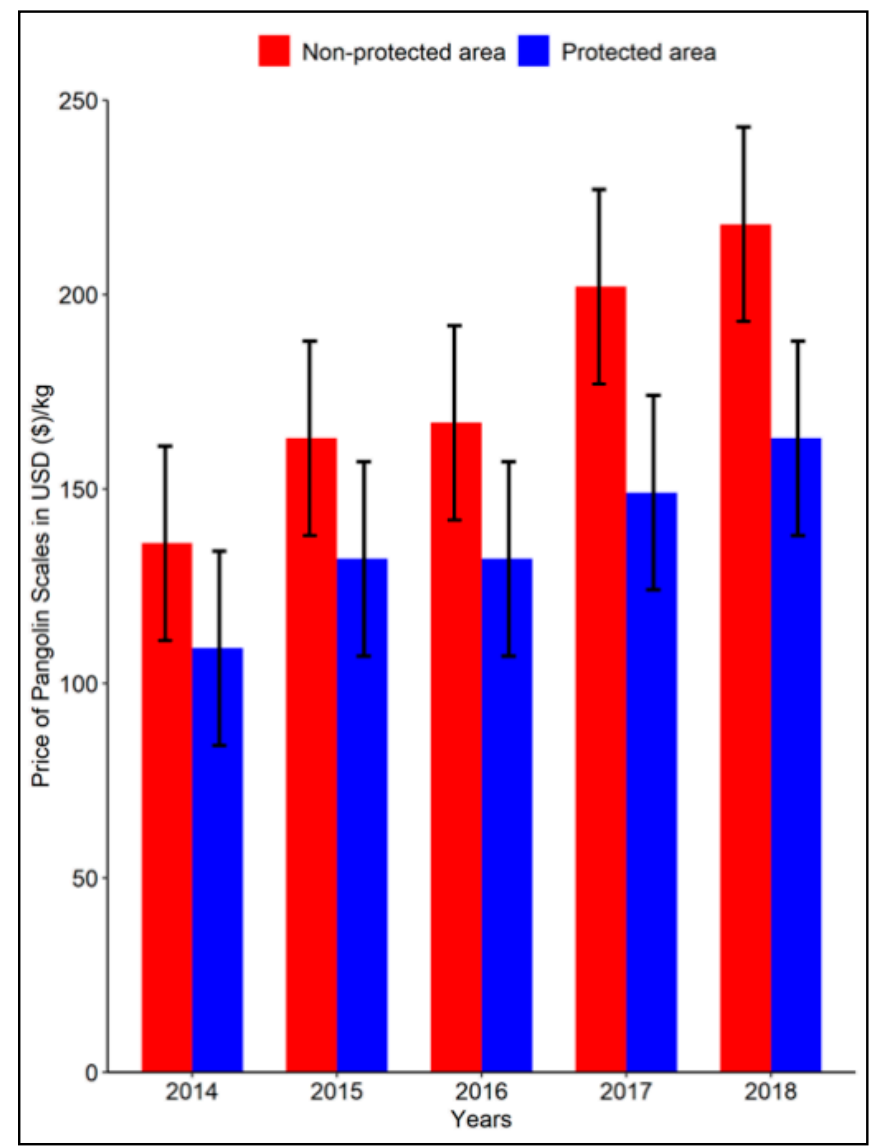

Figure 4. Chinese pangolin scales' price per $\mathrm{kg}$. The price was based on the seized samples between 2014 and 2018.

\section{Discussion}

The illegal trading of Chinese pangolins in Nepal is influenced by the socio-economic status of traders. Poorer people were more likely to be involved in the pangolin trade, as poaching and selling the animal and their parts contributed substantially to their economic livelihood [37,38], with poverty being a key driving factor of the illegal wildlife trade [25,39-42]. The cost to purchase pangolin scales is lower in Nepal than in other countries such as Myanmar (USD \$190-290/kg; [43]), China (USD \$759.15/kg), or Vietnam (USD \$484.91/kg; [44]). The price, which continues to increase, is likely due to an increase in transits, connections of traders with middlemen, an increasing demand, and an increasing scarcity of pangolins, as their population continues to significantly decline due in part to trade. The higher prices outside PAs might be due to more frequent connections with middle persons who raise prices. However, lower prices reported from people living inside the PA may be because people believe that pangolins are important to ecosystem services [29], which could reduce the perception of the value of pangolin scales. Nevertheless, all reported prices of pangolin scales are high relative to the annual median income of people in Nepal (USD \$1026; https://data.worldbank.org/country/nepal <accessed on 30 September 2019>), providing further support for people's willingness to become involved in illegal trade. Finally, unemployed people were also engaged in the pangolin trade, as time spent unemployed would allow more time to be spent in these illegal activities [45].

Individuals may also be involved in the pangolin trade for simple sustenance reasons, as eating pangolins can offer a source of protein and selling them can offer an income they may not otherwise have [46,47]. The individuals selling pangolins often use their traditional knowledge of pangolin body parts for medicines; however, the majority of them do not know the reasoning behind these uses (S. S. personal communication). This type of knowledge lacks in other countries' indigenous people (e.g., the Hmong people in Laos) [48]. Cultural norms in the male-dominated Nepalese society, such as 
the freedom males have to engage with others without restriction from their family, could explain the greater involvement of men in the pangolin trade [49,50]. In addition, men are generally more likely to admit to sensitive behaviors compared to women [51].

Due to family member expectations for people of working age to contribute economically to household livelihood, people of the working age group may be more likely to become involved in wildlife trade [45]. Consequently, more people of working age in Nepal were involved in the pangolin trade. Similarly, illiterate people of working age in this study were likely involved in the illegal pangolin trade to obtain adequate financial resources to meet basic needs, as suggested by Katuwal et al. [4], due to highly limited employment opportunities $[38,41]$. Providing more income generating opportunities (e.g., ecotourism) and keeping this revenue within local communities might further motivate people to conserve pangolins. Further, incorporating additional agricultural technologies and animal husbandry practices will also assist in the conservation of pangolins, as most local people already have positive attitudes toward wildlife conservation [52]. In addition, strict enforcement of existing rules and regulations regarding wildlife and an increased awareness of the legal protection status of species might motivate people towards the conservation [52]. Information regarding the legal protection of these species and their conservation could also be integrated into school curricula.

From the results, we found that people from both the PA and non-PA were involved in the pangolin trade, but poachers from each area used different trade routes. Nevertheless, the final destination in Nepal was typically the border to China $[4,28,38]$. Illegal wildlife trades generally occur through a complicated network of locations and routes to avoid detection before its final destination [53,54], and this was supported by our findings. Likewise, Katuwal et al. [4] found alternative routes for illegal pangolin trade activities, and most traders transported pangolins and their derivatives to the border with China, though the traders may have transported the wildlife products to China through India due to the open border between Nepal and India [55]. Nepali people were banned from crossing the border to China after an earthquake in 2015; consequently and soon thereafter, people began to use the Kathmandu-Kerung route for trading [56]. This may explain the large number of current alternative trade routes we identified in this study. The Kathmandu-Tibet highway has since reopened; thus, traders may again be using this route.

To help mitigate the pangolin trade, we recommend the establishment of community-based anti-poaching units to work in coordination with district-level Wildlife Crime Control Bureau and central-level Wildlife Crime Control Bureau and National Wildlife Crime Control Coordination Committee for working together for enhancing law enforcement. We suggest also including the South Asia Wildlife Enforcement Network in a system to collaborate to reduce wildlife crime among the range countries and trade route countries. Based on this information, we recommend that the Nepalese government take additional steps to control pangolin trade, for example, increasing anti-poaching patrols in areas of known or suspected pangolin trade. These anti-poaching units can establish relationships with local law enforcement officials and people who collectively can inform anti-poaching units of illegal trade as well as increase awareness of illegal activities and promote the need for pangolin conservation.

From our findings, we suggest that the socio-economic status of local people has facilitated illegal pangolin trading in central Nepal. We further found that the higher price of pangolin parts outside Nepal, particularly in China, coupled with the low annual income of Nepali may be facilitating the increased transport of pangolins and their derivatives among an increasing number of alternative routes to the Chinese border. We recommend continued efforts by the Government of Nepal to increase local peoples' income through income-generating sources such as ecotourism, or by providing incentives to promote other local industries. We also recommend more diligent patrolling along reported trade routes and an increase in security along the China-Nepal border to reduce transboundary transportation of Chinese pangolins and their body parts in collaboration with local people. Finally, reducing the demand for pangolins from within China could reduce incentives for their illegal trade (e.g., [20]) and instead promote the conservation of this species long-term. 
Supplementary Materials: The following is available online at http://www.mdpi.com/2071-1050/12/12/4900/s1, Table S1: People's knowledge of illegal Chinese pangolin trade routes in central Nepal.

Author Contributions: Conceptualization, S.S., H.P.S., and H.B.K.; formal analysis, S.S., H.P.S., and H.B.K.; funding acquisition, S.S. and J.L.B.; investigation, S.S. and C.C.; writing-original draft, S.S., H.P.S., and H.B.K.; writing-review and editing, S.S., H.P.S., H.B.K., C.C., and J.L.B. All authors have read and agreed to the published version of the manuscript.

Funding: Rufford Small Grant Foundation (Grant No. 26508-2), Fresno Chaffee Zoo, and Camp Fire Conservation Fund.

Acknowledgments: We thank the Department of National Parks and Wildlife Conservation (Permission number: 564), Department of Forest, Divisional Forest Office of Ramechhap, the Gaurishankar Conservation Area, Rajendra Karki, and Chandeshwor Pattel for assisting us in our project. We thank Eric Wikramanayake, Kumar Sapkota, Ugan Manandar, Damber Bista for their support and guidance. We appreciate the time, effort, and the comments from three anonymous reviewers who worked to improve our manuscript.

Conflicts of Interest: The authors declare no conflicts of interest.

\section{References}

1. Newton, P.; Van Thai, N.; Roberton, S.; Bell, D. Pangolins in peril: Using local hunters' knowledge to conserve elusive species in Vietnam. Endanger. Species Res. 2008, 6, 41-53. [CrossRef]

2. Jnawali, S.R.; Baral, H.S.; Lee, S.; Subedi, N.; Acharya, K.P.; Upadhyay, G.P.; Pandey, M.; Shrestha, R.; Joshi, D.; Lamichhane, B.R.; et al. The status of Nepal's Mammals: The National Red List Series; Department of National Parks and Wildlife Conservation: Kathmandu, Nepal, 2011.

3. Baker, F. Assessing the Asian Industry Link in the Intercontinental Trade of African Pangolin, Gabon. Master's Thesis, Imperial College London, London, UK, 2014.

4. Katuwal, H.B.; Neupane, K.R.; Adhikari, D.; Sharma, M.; Thapa, S. Pangolins in eastern Nepal: Trade and ethno-medicinal importance. J. Threat. Taxa 2015, 7, 7563-7567. [CrossRef]

5. Challender, D.; Waterman, C. Implementation of CITES Decision2 17.239 b) and 17.240 on Pangolins (Manis spp.); Prepared by IUCN for the CITES Secretariat. SC69 Doc; IUCN: Gland, Switzerland, 2017; Volume 57.

6. Challender, D.; Wu, S.; Kaspal, P.; Khatiwada, A.; Ghose, A.; Ching-Min Sun, N.; Mohapatra, R.K.; Laxmi Suwal, T. Manis Pentadactyla. The IUCN Red List of Threatened Species 2019: E.T12764A168392151. Available online: https://dx.doi.org/10.2305/IUCN.UK.2019-3.RLTS.TI2764A168392151.en (accessed on 15 November 2019).

7. Heinrich, S.; Wittman, T.A.; Ross, J.V.; Shepherd, C.R.; Challender, D.W.S.; Cassey, P. The Global Trafficking of Pangolins: A Comprehensive Summary of Seizures and Trafficking Routes from 2010-2015; TRAFFIC; Southeast Asia Regional Office: Petaling Jaya, Selangor, Malaysia, 2017.

8. Department of National Parks and Wildlife Conservation. Pangolin Conservation Action Plan for Nepal (2018-2022); Department of National Parks and Wildlife Conservation and Department of Forests: Kathmandu, Nepal, 2018.

9. Zhou, Z.M.; Zhou, Y.; Newman, C.; Macdonald, D.W. Scaling up pangolin protection in China. Front. Ecol. Environ. 2014, 12,97-98. [CrossRef]

10. Davis, E.O.; Glikman, J.A.; Crudge, B.; Dang, V.; Willemsen, M.; Nguyen, T.; O'Connor, D.; Bendixen, T. Consumer demand and traditional medicine prescription of bear products in Vietman. Biol. Conserv. 2019, 235, 119-127. [CrossRef]

11. Challender, D.W.S.; Sas-Rolfes, M.; Ades, G.W.J.; Chin, J.S.C.; Sun, N.C.-M.; Chong, J.U.; Connelly, E.; Hywood, L.; Luz, S.; Mohapatra, R.K.; et al. Evaluating the feasibility of pangolin farming and its potential conservation impact. Glob. Ecol. Conserv. 2019, 20, e00714. [CrossRef]

12. Crudge, B.; Nguyen, T.; Cao, T.T. The challenges and conservation implications of bear bile farming in Viet Nam. Oryx 2018, 54, 252-259. [CrossRef]

13. Katuwal, H.B.; Sharma, H.P.; Parajuli, K. Anthropogenic impacts on the occurrence of the critically endangered Chinese pangolin (Manis pentadactyla) in Nepal. J. Mammal. 2017, 98, 1667-1673. [CrossRef]

14. Sharma, H.P.; Rimal, B.; Zhang, M.; Sharma, S.; Poudyal, L.P.; Maharjan, S.; Kunwar, R.; Kaspal, P.; Bhandari, N.; Baral, L.; et al. Potential distribution of the critically endangered Chinese Pangolin (Manis pentadactyla) in different land covers of Nepal: Implications for conservation. Sustainability 2020, 12, 1282. [CrossRef] 
15. Sharma, S.; Sharma, H.P.; Chaulagain, C.; Katuwal, H.B.; Belant, J.L. Estimating occupancy of Chinese pangolin (Manis pentadactyla) in a protected and non-protected area of Nepal. Ecol. Evol. 2020, 10, 4303-4313. [CrossRef]

16. CITES. Prop. 11.13. Manis crassicaudata, Manis pentadactyla, Manis javanica. Transfer from Appendix II to Appendix I (India, Nepal, Sri Lanka, United States). 2000. Available online: https://www.cites.org/eng/app/ appendices.php (accessed on 16 June 2020).

17. Chukwuone, N.A. Socio-economic determinants of cultivation of non-wood forest products in southern Nigeria. Biodiver. Conserv. 2009, 18, 339-353. [CrossRef]

18. Rao, M.; McGowan, P.J.K. Wild-meat use, food security, livelihoods, and conservation. Conserv. Biol. 2002, 16, 580-583.

19. Milliken, T. Illegal Trade in Ivory and Rhino Horn: An Assessment Report to Improve Law Enforcement under Wildlife TRAPS Project; USAID and TRAFFIC, International: Cambridge, UK, 2014.

20. Duffy, R. Nature Crime: How we're Getting Conservation Wrong; New Haven, Yale University Press: New Haven, CT, USA; London, UK, 2010.

21. IFAW. Killing with Keystrokes: An Investigation of the Illegal Wildlife Trade on the World Wide Web; IFAW: Brussels, Belgium, 2008.

22. TRAFFIC. What's Driving the Wildlife Trade? A Review of Expert Opinion on Economic and Social Drivers of the Wildlife Trade and Trade Control Efforts in Cambodia, Indonesia, Lao PDR and Vietnam; World Bank: Washington, DC, USA, 2008.

23. Biggs, D.; Cooney, R.; Roe, D.; Dublin, H.; Allan, J.; Challender, C.; Skinner, D. Engaging Local Communities in Tackling Illegal Wildlife Trade: Can a 'Theory of Change' Help? Discussion Paper; IIED: London, UK, 2015.

24. Brack, D.; Hayman, G. International Environmental Crime: The Nature and Control of Environmental Black Markets; The Royal Institute of International Affairs: London, UK, 2002.

25. Adams, W.M.; Aveling, R.; Brockington, D.; Dickson, B.; Elliott, J.; Hutton, J.; Roe, D.; Vira, B.; Wolmer, W. Biodiversity conservation and the eradication of poverty. Science 2004, 306, 1146-1149. [CrossRef] [PubMed]

26. Borgerhoff-Mulder, M.; Coppolillo, P. Conservation: Linking Ecology, Economics, and Culture; Princeton University Press: Princeton, NJ, USA, 2005.

27. Ostrom, E. Governing the Commons: The Evolution of Institutions for Collective Action; Cambridge University Press: Cambridge, UK, 1990.

28. Kaspal, P.; Shah, K.B.; Baral, H.S. Saalak (i.e., Pangolin); Himalayan Nature: Kathmandu, Nepal, 2016.

29. Sharma, S.; Sharma, H.P.; Katuwal, H.B.; Belant, J.L. Knowledge of the Critically Endangered Chinese pangolin (Manis pentadactyla) by local people in Sindhupalchok, Nepal. Glob. Ecol. Conserv. 2020, e01052. [CrossRef]

30. DNPWC. Protected Areas of Nepal; Department of National Parks and Wildlife Conservation: Kathmandu, Nepal, 2012.

31. Bhattachan, K.B. Country Technical Notes on Indigenous Peoples' Issues Federal Democratic Republic of Nepal; International Fund for Agricultural Development: Rome, Italy, 2012.

32. CBS. National Population and Household Census 2011; National report submitted to Government of Nepal; National Planning Commission Secretariat, Central Bureau of Statistics: Kathmandu, Nepal, 2012.

33. NRCA. Initial Environmental Examination of Deitar-Phulasipokhari Section of Devitar-Doramba-Paseban-Kolibagar Road Rehabilitation Sub-Project; Ramechhap district. A report prepared by District Coordination Committee, Ramechhap and submitted to Government of Nepal, National Reconstruction Authority through Government of Nepal; Ministry of Federal Affairs and Local Development Earthquake Emergency Assistance Project: Ramechhap, Nepal, 2017.

34. Yamane, T. Statistics: An Introductory Analysis, 2nd ed.; Harper and Row: New York, NY, USA, 1967.

35. MacNamara, J.; Rowcliffe, M.; Cowlishaw, G.; Alexander, J.S.; Ntiamoa-Baidu, Y.; Brenya, A.; Milner-Gulland, E.J. Characterising wildlife trade market supply-demand dynamics. PLoS ONE 2016, 11, e0162962. [CrossRef]

36. Bennett, L.; Dahal, D.R.; Govindasamy, P. Caste, Ethnic and Regional Identity in Nepal: Further Analysis of the 2006 Nepal Demographic and Health Survey; Macro International Inc: Calverton, MD, USA, 2008.

37. Loibooki, M.; Hofer, H.; Campbell, K.L.I.; East, M.L. Bushmeat hunting by communities adjacent to the Serengeti National Park, Tanzania: The importance of livestock ownership and alternatie sources of protein and income. Environ. Conserv. 2002, 29, 391-398. [CrossRef] 
38. Ghimire, P.; Raut, N.; Khanal, P.; Acharya, S.; Upadhaya, S. Species in peril: Assessing the status of the trade in pangolins in Nepal. J. Threat. Taxa. 2020, 12, 15776-15783. [CrossRef]

39. MacKenzie, C.; Chapman, C.A.; Sengupta, R. Spatial patterns of illegal resource extraction in Kibale National Park, Uganda. Env. Conserv. 2011, 39, 38-50. [CrossRef]

40. Nellemann, C.; Henricksen, R.; Raxter, P.; Ash, N.; Mrema, E. (Eds.) The Environmental Crime Crisis-Threats to Sustainable Development from Illegal Exploitation and Trade in Wildlife and Forest Resources; A UNEP Rapid Response Assessment; UN Environment Programme and GRID-Arendal: Nairobi, Kenya; Arendal, Norway, 2014.

41. Katuwal, H.B.; Parajuli, K.; Sharma, S. Money overweighed the traditional beliefs for hunting of Chinese pangolins in Nepal. J. Biodivers. Endanger. Species 2016, 4, 173. [CrossRef]

42. Twinamatsiko, M.; Baker, J.; Harrison, M.; Shirkhorshidi, M.; Bitariho, R.; Wieland, M.; Asuma, S.; Milner-Gulland, E.J.; Franks, P.; Roe, D. Linking Conservation, Equity and Poverty Alleviation: Understanding Profiles and Motivations of Resource Users and Local Perceptions of Governance at Bwindi Impenetrable National Park, Uganda; IIED Resources Report: London, UK, 2014.

43. Zhang, M.; Gouveia, A.; Qin, T.; Quan, R.; Nijman, V. Illegal pangolin trade in Northernmost Myanmar and its links to India and China. Glob. Ecol. Conserv. 2017, 10, 23-31. [CrossRef]

44. Challender, D.W.S.; Harrop, S.R.; MacMillan, D.C. Understanding markets to conserve trade-threatened species in CITES. Biol. Conserv. 2015, 187, 249-259. [CrossRef]

45. Lindsey, P.; Balme, G.; Becker, M.; Begg, C.; Bento, C.; Bocchino, C.; Dickman, A.; Diggel, R.; Eves, H.; Henschel, P.; et al. Illegal Hunting and the Bush-Meat Trade in Savanna Africa: Drivers, Impacts and Solutions to Address the Problem; Panthera/Zoological Society of London/Wildlife Conservation Society report: New York, NY, USA, 2015. Available online: http//www.fao.org/3/a-bc609e.pdf (accessed on 21 November 2019).

46. Pangau-Adam, M.; Noske, R.A. Wildlife hunting and bird trade in north-east Papua (Irian Jaya), Indonesia. In Ethno-Ornithology: Birds, Indigenous Peoples, Culture and Society; Tidemann, S., Gosler, A., Gosford, R., Eds.; Earthscan: London, UK, 2010.

47. Paudel, K.; Potter, G.R.; Phelps, J. Conservation enforcement: Insights from people incarcerated for wildlife crimes in Nepal. Conserv. Sci. Prac. 2020, 2, e137. [CrossRef]

48. Davis, E.O. Understanding Use of Bear Products in Southeast Asia: Human-Oriented Perspectives from Cambodia and Laos. Ph.D. Thesis, University of Bristol, Bristol, UK, 2019.

49. Agarwal, B. Participatory exclusions, community forestry, and gender: An analysis for South Asia and a conceptual framework. World Dev. 2001, 29, 1623-1648. [CrossRef]

50. Pokharel, S. Gender discriminatory practices in Tamang and Brahmin communities. Tribhuvan Univ. J. 2009, 26, 85-98. [CrossRef]

51. McElwee, P. The Gender Dimensions of the illegal trade in wildlife: Local and global connections in Vietnam. In Gender and Sustainability: Lessons from Asia and Latin America; Cruz-Torres, M.L., McElwee, P., Eds.; University of Arizona Press: Tucson, AZ, USA, 2012.

52. Sharma, H.P.; Belant, J.L.; Shaner, P.J.L. Attitudes towards conservation of the Endangered red panda Ailurus fulgens in Nepal: A case study in protected and non-protected areas. Oryx 2019, 53, 542-547. [CrossRef]

53. Lin, J. Tackilng southeast Asia's Illegal wildlife trade. SYBIL 2005, 9, 191-208.

54. Heinrich, S.; Wittmann, T.A.; Prowse, T.A.A.; Ross, J.V.; Delean, S.; Sepherd, C.R.; Cassey, P. Where did all the pangolins go? International CITES trade in pangolin species. Glob. Ecol. Conserv. 2016, 8, 241-253. [CrossRef]

55. Dangol, B.R. Illegal wildlife trade in Nepal: A case study from Kathmandu Valley. Master's Thesis, Norwegian University of Life Science, Faculty of Life Science, Oslow, Norway, 2015.

56. Shrestha, A.B.; Bajracharya, S.R.; Kargel, J.S.; Khanal, N.R. The Impact of Nepal's 2015 Gorkha Earthquake-Induces Geohazards; ICIMOD: Kathmandu, Nepal, 2016.

(C) 2020 by the authors. Licensee MDPI, Basel, Switzerland. This article is an open access article distributed under the terms and conditions of the Creative Commons Attribution (CC BY) license (http://creativecommons.org/licenses/by/4.0/). 